\title{
Androgen Receptor Distribution, PAS and Alcyan Blue Reaction in the Vomeronasal Organ and the Nasal Septum Mucosa of the Developing Male Rat
}

\author{
Distribución del Receptor de Andrógeno, Positividad a PAS y Alcyan Blue en el Órgano \\ Vomeronasal y la Mucosa del Tabique Nasal Durante el Desarrollo de la Rata Macho
}

Núñez Chichet, M E.; Genovese, P. \& Bielli, A.

NÚÑEZ CHICHET, M E.; GENOVESE, P. \& BIELLI, A. Androgen receptor distribution, PAS and Alcyan Blue reaction in the vomeronasal organ and the nasal septum mucosa of the developing male rat. Int. J. Morphol., 25(3):579-585, 2007.

SUMMARY: The vomeronasal organ (VNO) is a tubular chemoreceptory organ which detects environmental pheromones and is essential for mammalian normal reproductive activity. A sensitive chemoreceptory neuroepithelium lines the concave VNO wall and the opposite, convex wall is lined by a seudostratified, receptor-free epithelium. The secretion of the Jacobson glands (JG) -tubuloacinary glands lying in the lamina propia of the VNO - is essential for pheromones contacting vomeronasal organ chemoreceptors. Tubuloacinary glands lying in the connective tissue of the nasal septum mucosa (Bowman glands), can be classified as ventral and dorsal, according to their location. Positivity to PAS and Alcyan blue reactions and androgen receptor immunolocalization was evaluated with a semiquantitative system ( $0,1,2$ or 3 crosses) in JG, ventral Bowman glands (VBG), dorsal Bowman glands (DBG), sensitive chemoreceptory neuroepithelium (Ne), receptor-free epithelium (RFE) and nasal septum respiratory epithelium (RE) histological slides of male rats at 5, 15, 25 and 35 days of age. The VBG and JG were intensely positive to PAS reaction since 5 days of age, and weakly positive to Alcyan blue reaction (AB) since 15 days of age, but not at 5 days of age. Both JG and VBG were strongly positive to androgen receptor immunolocalization at all ages studied (15, 25 and 35 days of age). DBG were always negative to both PAS and AB reactions. The NE and the RFE and nasal mucosa luminar epithelium were negative. To our knowledge, this is the first report of androgen receptor (AR) immunolocalization in the vomeronasal organ and the nasal septum mucosa. The present results also suggest an influence of androgens on the mechanism of pheromones contacting with the Ne of the VNO through regulation of the Jacobson glands secretion.

KEY WORDS: Vomeronasal organ; Chemoreception; Development; Histochemistry; Immunohistochemistry.

\section{INTRODUCTION}

The vomeronasal organ (VNO) is a chemoreceptory organ which detects environmental pheromones and is essential for mammalian normal reproductive activity (Keverne, 2004). It is tube-shaped, lies at both sides of the ventral nasal septum within a hard bony and cartilaginous capsule that lies at the base of the nasal septum (Wysocki, 1979) and its lumen is crescent-shaped (Vacarezza et al., 1981). A sensitive chemoreceptory microvillar neuroepithelium $(\mathrm{Ne})$ lines the concave VNO wall and the opposite, convex wall is lined by a ciliated seudostratified, receptor-free epithelium (RFE). The VNO varies in structure lengthwise (Vacarezza et al.) and can be divided along its longitudinal axis into four regions. Jacobson glands (JG) are located in the connective tissue underlying the RFE (Taniguchi et al., 1996). The secretion of the JG is essential for pheromones contacting VNO chemoreceptors (Eccles, 1982; Mendoza, 1986; Taniguchi et al., 1993). Bowman glands (BG) are similar tubuloacinary glands lying in the connective tissue of the nasal septum mucosa (Taniguchi et al., 1996).

Schiff's periodic acid (PAS) stain and Alcyan Blue (AB) stain are histochemical methods widely used to demonstrate mucous secretions. The PAS technique oxidizes 1,2-glycols into aldehyde groups, which then react with the Schiff reagent producing a magenta stain. Neutral polisaccharides are positive to PAS stain. On the other hand, $\mathrm{AB}$ technique evidences weakly acid sulfated mucinous substances producing a cyan stain (Merck KGaA, 2004). 
Oikawa et al. (1994) found chinchilla's (Chinchilla laniger) JG are positive to PAS reaction and negative to $\mathrm{AB}$ reaction. The morphology and histochemistry of the septal glands that empty into the nasal cavity has been described as either serous, mucous, or seromucous in nature (Roslinski et al., 2000). Alcyan blue and PAS reaction positivity varies between species: all JG are positive to PAS reaction in rats older than 7 days (Garrosa, 1986) whereas $\mathrm{JG}$ are negative to $\mathrm{AB}$ stain in pre and postnatal rats. However, Bowman glands are positive to $\mathrm{AB}$ reaction from 7 days of age on (Garrosa). Human JG but neither Microcebus murinus nor Microtus spp. are positive to $\mathrm{AB}$ reaction (Roslinski et al.). However, JG are positive to PAS reaction in all three species. In humans, the dorsal acini of the BG (DBG) are negative to PAS reaction (Katz \& Merzel, 1977), but most acini are PAS positive in the ventral BG (VBG) and in all JG. Consequently, there seems to be some degree of regional specialization in the secretion of JG and BG, with differences between species.

On the other hand, although the ontogeny of PAS and $\mathrm{AB}$ reaction has been described for rat $\mathrm{JG}$, no reports exist regarding rat $\mathrm{BG}$ PAS or $\mathrm{AB}$ reaction. Furthermore, none of the previous papers described what region was sampled in spite that it is well stablished that the VNO's four anatomical regions differ widely in structure.

Androgens are essential for normal male reproduction and development. Androgen receptor (AR) is a member of the steroid and nuclear receptor protein superfamily (Freedman, 1998). Androgen receptor is a soluble protein that is present in the cytoplasm linked to heat shock proteins and upon agonist binding, it translocates to the nucleus (Gao et al., 2005). Thus, AR location indicates sites of androgen action. No description exists regarding AR localization in the VNO and the nasal septum mucosa.

The objective of the present work was to study PAS positivity, $\mathrm{AB}$ positivity and $\mathrm{AR}$ immunolocalization in the VNO most caudal region and the neighboring nasal septum mucosa during postnatal life and puberty in the male rat.

\section{MATERIAL AND METHOD}

Animals and sampling procedures. All procedures described below were carried out following rules described by the Committee of Animal Ethical Management of the Veterinary Faculty of Uruguay. Five Sprague-Dawley virgin 2-month-old female rats were mated by the same male. After parturition, pups were interchanged to arrange five 8-pups litters, where at least 7 pups were males. Pups (total $n=56$ ) were weaned at 20 days of age and fed thereafter with standard rat chow. Pups were weighed every other day and slaughtered $(n=7)$ at $5,15,25$ and 35 days of age. Rats were decapitated, their snouts cut out, skin and superficial soft tissues trimmed away, and the remaining sample was immersion-fixed in $4 \%$ buffered formaline, $\mathrm{pH}=7.2$. After 7 days fixation, samples were decalcified in $14 \%$ ethilen diamino tetra acetic acid solution until snout bones became flexible. Samples were then sectioned so that the VNO was divided into four pieces of similar length. The caudalmost piece was dehydrated in increasingly concentrated ethanol solutions and embedded into paraffin wax. Samples were sectioned serially from the caudal end of the VNO. When VNO lumina became patent in the resulting sections, fifteen $7 \mu \mathrm{m}$-thick histological sections per animal were mounted on sylanised glass slides ( 5 sections/slide). The first 5 sections per animal were used to study AR localization, the next 5 sections to study PAS reaction localization and the last 5 sections to study $\mathrm{AB}$ localization.

To study PAS positivity, sections were oxidized in $1 \%$ periodic acid solution (1g sodium periodate, distilled water up to $100 \mathrm{~mL}$ ), rinsed in distilled water, immersed in Schiff's stain for 10 min., rinsed again and stained with Meyer's haematoxylin, dehydrated, cleared and mounted.

To study Alcyan Blue positivity, sections were stained with Alcyan Blue solution (1.0 g Alcyan Blue 8GX stain in $100 \mathrm{~mL}, 0.1 \mathrm{~N}$ chlorhydric acid) for $30 \mathrm{~min}$., dried with filter paper, dehydrated, cleared and mounted. In order to study AR localization, antigens in sylanised sections were exposed by humid heat incubation in $0,3 \%$ buffer citrate solution $(\mathrm{pH}=7.5)$, treated with a mouse primary antibody (AR441, Dako Cytomation, Carpinteria, CA, USA) anti human AR diluted 1:15, and developed with a streptavidinbiotin commercial kit (LSAB+, Dako Cytomation, Carpinteria, CA, USA). Positive substances were evidenced with 5 min DAB stain (diamino bencidine) incubation. A slide which was not treated with the primary antibody was used as a negative control.

Histological slides were evaluated blindly by two experienced observers with a semiquantitative system $(0$, 1,2 or 3 crosses) in a light microscope (Olympus BX 50, Tokyo, Japan) at 400x. Staining positivity was evaluated in 6 histological structures: JG, VBG, DBG, VNO neuroepithelium $(\mathrm{Ne}), \mathrm{VNO}$ receptor-free epithelium (RE) and nasal septum respiratory epithelium (NRE) for all three techniques used.

Body weights were expressed as means \pm SD. Body weight differences between ages were studied by repeated measures Anova with differences at $\mathrm{P} \leq 0.05$. 


\section{RESULTS}

Body weights at slaughter day increased along the experiment ( 5 days of age: $16.49 \pm 0.84 ; 15$ days of age: $29.24 \pm 1.98 ; 25$ days of age: $674.29 \pm 7.45 ; 35$ days of age: $104.33 \pm 6.56)$. Staining results are shown in Table I.

PAS reaction (Figs. 2. A, D, G, J, M).

Both JGs and VBGs were positive to PAS reaction but staining was more intense in VBGs. PAS reaction intensity increased slightly from 5 to 15 days of age but did not change later. Dorsal Bowman glands were negative. The NRE was positive (goblet cells). The VNO's Ne showed positive material only in its luminal surface. The VNO's RFE was negative except for a few positive epithelial cells which looked similar to goblet cells.

Alcyan Blue reaction. (Figs. 2. B, E, H, K, N).
Both JGs and VBGs were mildly positive to $\mathrm{AB}$ technique but DBGs were negative. Alcyan blue reaction intensity increased slightly from 5 to 15 days of age both in VBG and JG but did not change later. The NRE was intensely positive to $A B$ reaction at all ages studied (in goblet cells) although it was slightly weaker at 5 days of age than later. The VNO's Ne and RFE showed material positive to AB reaction only on their luminal surfaces. Such material showed stronger positivity on the RFE surface.

Androgen receptor immunolocalization (Figs. 2. C, F, I, L, O).

Several slides belonging to the 5 days of age group were wiped off. Consequently, the entire group was eliminated for AR detection. Both JGs and VBGs were strongly positive to AR immunolocalization at all ages studied (15, 25 and 35 days of age). Dorsal Bowman glands were weakly positive. The VNO's Ne and RFE and the NRE were negative.

\section{Dorsal Zone of the Nose}

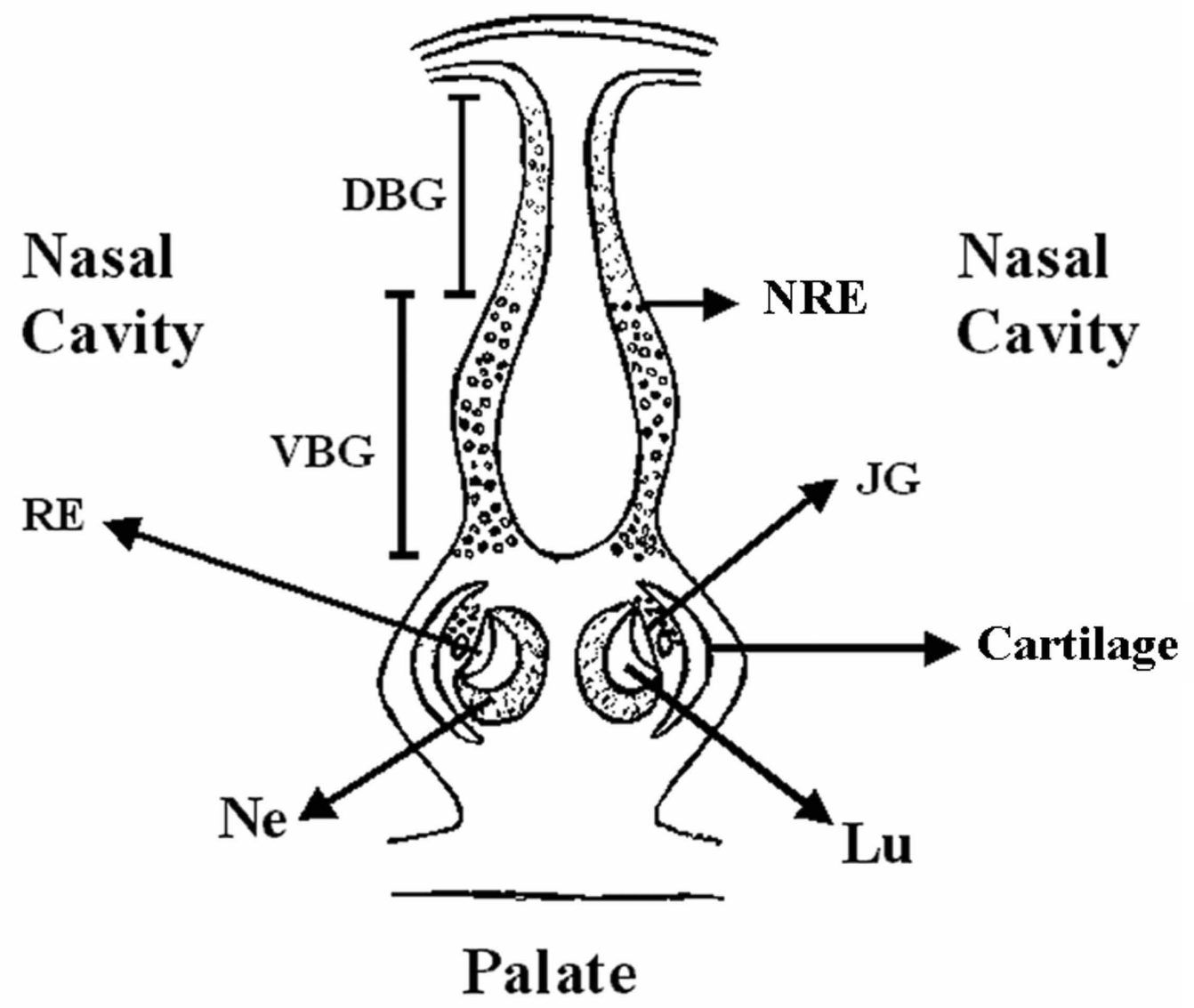

Fig. 1. The nasal septum of the rat at the VNO's caudalmost region. Location of the VNO and its luminal epithelia, neighboring glands and NRE. 


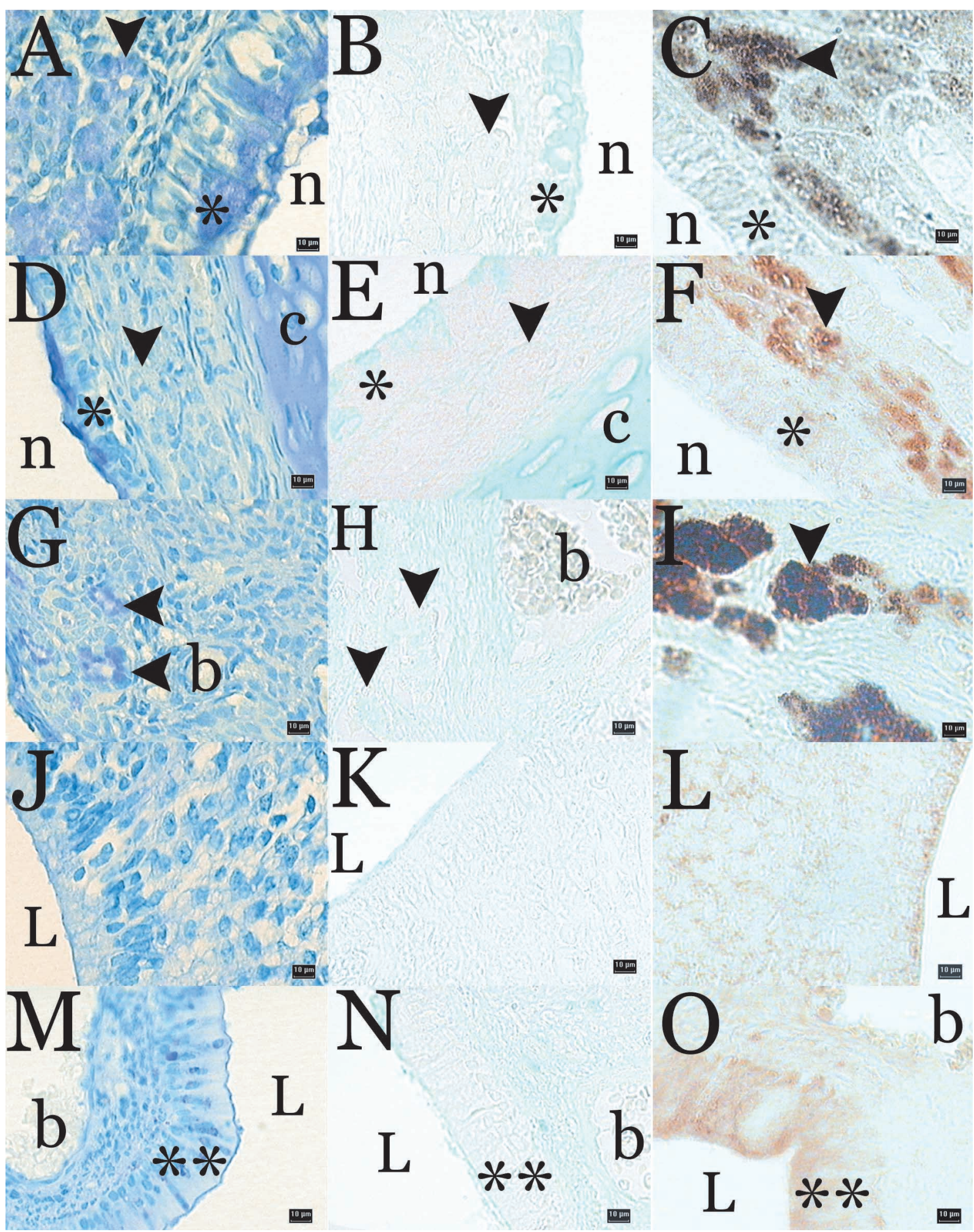

Fig. 2. Ventral Bowman's glands and nasal respiratory epithelium in rats: Fig. A.- 15 days, PAS-Haematoxylin technique (arrow head $)=$ VBG, $(*)=$ NRE, $n=$ nasal cavity; Fig. B.- 5 days, AB technique; Fig. C.- 25 days, AR immunopositivity. Dorsal Bowman's glands and nasal respiratory epithelium in rats: Fig. D.- 35 days, PAS-Haematoxylin technique, $(\operatorname{arrow}$ head) $=$ DBG, $(*)=$ nasal respiratory epithelium, $c=$ cartilage; Fig. E.- 15 days, AR immunopositivity; Fig. F.- 25 days, AB technique. Jacobson's glands in rats: Fig. G.- 5 days, PAS-Haematoxylin technique, (arrow head) = JG, (b)= blood vessels; Fig. H.- 25 days, AR immunopositivity; Fig. I.- 15 days, AB technique. Vomeronasal neuroepithelium of the vomeronasal organ in rats: Fig. J.- 25 days, Ne, PAS-Haematoxylin technique, L = lumen of the VNO; Fig. K.- 5 days, AB technique; Fig. L.- 35 days, AR immunopositivity. Receptor-free epithelium of the vomeronasal organ in rats: Fig. M.- 5 days, PAS-Haematoxylin technique, $(* *)=$ RFE; Fig. N.- 25 days, AB technique; Fig. O.- 35 days, with AR immunopositivity. Bar $=10 \mu \mathrm{m}$. 
Table I. Distribution of PAS and AB reaction positivity and immunolocalization (AR) of androgen receptor in VNO's Ne, surface of Ne, RFE, surface of RFE, JG, DBG and VBG and in the NRE of the septum in rats of 5, 15, 25 and 35 days of age. IHC=immunohistochemistry.

\begin{tabular}{|c|c|c|c|c|c|c|c|c|c|}
\hline \multirow{3}{*}{ AGE (days) } & \multirow{3}{*}{ Technique } & \multirow{3}{*}{ DBG } & \multirow{3}{*}{ VBG } & \multirow{3}{*}{ JG } & \multirow{3}{*}{ NRE } & \multicolumn{4}{|c|}{ VNO } \\
\hline & & & & & & \multicolumn{2}{|c|}{$\mathrm{Ne}$} & \multicolumn{2}{|c|}{ RFE } \\
\hline & & & & & & Epithelium & Surface & Epithelium & Surface \\
\hline $5(\mathrm{n}=6)$ & PAS & 0 & 3 & 1 & 2 & 0 & 1 & $\mathrm{~T}$ & 1 \\
\hline $15(\mathrm{n}=6)$ & PAS & 0 & 2 & 2 & 2 & 0 & 2 & 1 & 1 \\
\hline $25(\mathrm{n}=6)$ & PAS & 0 & 3 & 2 & 2 & 0 & 2 & 2 & 1 \\
\hline $35(n=6)$ & PAS & 0 & 3 & 2 & 2 & 0 & 2 & 3 & 1 \\
\hline $5(\mathrm{n}=6)$ & $\mathrm{AB}$ & 0 & 0 & 1 & 2 & 0 & 1 & 0 & 2 \\
\hline $15(\mathrm{n}=6)$ & $\mathrm{AB}$ & 0 & 1 & 2 & 3 & 0 & 1 & 0 & 2 \\
\hline $25(\mathrm{n}=6)$ & $\mathrm{AB}$ & 0 & 2 & 2 & 3 & 0 & 1 & 0 & 2 \\
\hline $35(\mathrm{n}=6)$ & $\mathrm{AB}$ & 0 & 1 & 2 & 3 & 0 & 1 & 0 & 2 \\
\hline $15(\mathrm{n}=6)$ & AR IHC & 1 & 2.5 & 2 & 0 & 0 & 0 & 0 & 0 \\
\hline $25(\mathrm{n}=6)$ & AR IHC & 1 & 2.5 & 3 & 0 & 0 & 0 & 0 & 0 \\
\hline $35(\mathrm{n}=6)$ & AR IHC & 1 & 2 & 2 & 0 & 0 & 0 & 0 & 0 \\
\hline
\end{tabular}

\section{DISCUSSION}

PAS reaction. The pattern we found for PAS reaction positivity in VBG and JG has already been reported for rats (Garrosa et al.) and humans (Roslinski et al.). The pattern we found in DBG is similar to what was found in humans (Roslinski et al.) but has not been reported for rats previously. Furthermore, the slight layer of AB- and PAS- positive material we found coating the VNO's Ne and the RFE has already been reported for Microtus and Microcebus (and suggested as a characteristic of the luminal environment) and for humans, where secretions were most copious (Roslinski et al.).

Alcyan Blue reaction. Our results show weak $A B$ reaction in VBG and JG at 15, 25 and 35 days of age, and not at 5 days of age, whereas Garrosa et al. found no $\mathrm{AB}$ stain positivity in pre and postnatal rats. Roslinski et al. found $\mathrm{AB}$ reaction in human JG but not in Microcebus murinus and Microtus spp. The AB stain positivity we found in the VNO epithelial apical surfaces (both Ne and RFE) is probably caused by dispersion of JG's secretion. The VBG acini showed heterogeneous PAS and $\mathrm{AB}$ positivities indicating that at least in developing rats, most acini are seromucous in nature. We did not find any purely mucous acini. The increase with age in glands positivity to PAS and $\mathrm{AB}$ reactions is probably due to increases in volume or changes in the composition of their secretion. Both possibilities suggest changes in VNO function as rats grow. The PAS and $\mathrm{AB}$ reactions positivity in the surface of both VNO's epithelia seems to be caused by a thin layer of JG's secretion, since no positive structures were seen deeper within the epithelia.
Roslinski et al. observed that the RFE had unicellular mucous glands and cilia (both AB and PAS-positive), similar to respiratory epithelia, but did not find such cells in Microcebus murinus nor in Microtus spp. We have found PAS positive cylindrical cells in the rat RFE. This positivity increases as rats grow, at least until 35 days of age. Although such PAS positive cells have not been found either in Microcebus murinus or in Microtus spp they might be similar to the PAS positive cells found by Roslinski in humans. The differences in AB and PAS reaction between VNO's RFE and NRE suggest differences in secretion composition between such epithelia. Similar differences in secretion composition can be inferred between dorsal and ventral BG considering $\mathrm{AB}$ and $\mathrm{PAS}$ reactions, although such differences appear later in life (15 days of age) for AB stain. Androgen receptor immunolocalization To our knowledge, this is the first report of AR immunolocalization in the VNO and the nasal septum mucosa. The VNO is important for pheromone detection and thus for reproductive activity. We would expect some influence of androgens on VNO activity. Androgen exposure history determines reactivity to pheromone exposure (Dominguez-Salazar et al., 2002). Muroi et al. (2006) have recently demonstrated a competitive effect of androgen on pheromone detection in mice. The fact that AR has not been detected in the VNO Ne suggests that in case androgen influences pheromone detection in rats it exerts its action at some other site. Meredith had suggested one of such sites is probably the central nervous system. Another site where such influences might act are the JG, since their secretion is necessary for pheromones reaching $\mathrm{VNO} \mathrm{Ne}$ 
and the positivity of JG epithelial cells to AR indicates their activity is androgen dependent. The uneven distribution of AR in BGs suggests regional specialization, with VBGs situated closer to the VNO being similar to JG and different in AR sensitivity to DBG, whose sensitivity to androgens seems to be very slight if any at all. In conclusion, we have described the postnatal ontology of PAS and AB reaction in the caudal VNO and nasal septum mucosa and have reported for the first time AR immunolocalization in these organs. The present results suggest differences in secretion composition between VNO's RFE and NRE, and also suggest an influence of androgens on the mechanism of pheromones contacting with the VNO Ne through regulation of the JG secretion.

ACKNOWLEDGEMENTS. Alejandra Berglavaz and Carolina Pombo helped with rat management. Natalia Núñez, Sandra Carabetta, Zully Ramos, Stephany Lara, Paola Sosa, Carla Correa, Andrea Fernández, Karina Casaux, Hivanna Collo, Elena Reyes, Tania Zanoniani, Fernando Ayala collaborated with sampling.

NÚÑEZ CHICHET, M E.; GENOVESE, P. \& BIELLI, A. Distribución del receptor de andrógeno, positividad a PAS y Alcyan Blue en el órgano vomeronasal y la mucosa del tabique nasal durante el desarrollo de la rata macho. Int. J. Morphol., 25(3):579-585, 2007.

RESUMEN: El órgano vomeronasal (VNO) es un órgano quimioreceptor, tubular, que detecta feromonas ambientales. Es esencial para la actividad reproductiva normal de los mamíferos. El VNO está formado por un neuroepitelio quimiosensible (pared cóncava, $\mathrm{Ne}$ ) y un epitelio pseudoestratificado (epitelio libre de receptores: RFE) en la pared opuesta, convexa. La secreción de las glándulas tubuloacinares de Jacobson (JG), ubicadas en la lámina propia del VNO, son esenciales para que las feromonas entren en contacto con el Ne. Las glándulas tubuloacinares ubicadas en la mucosa del tabique nasal (glándulas del Bowman), se pueden clasificar como ventrales (VBG) y dorsales (DBG), según su localización. La positividad a las técnicas de PAS, Azul de Alcián (AB) e immunolocalización del receptor de andrógeno (AR), fueron evaluadas con un sistema semicuantitativo ( $0,1,2$ o 3 cruces) en láminas histológicas de JG, VBG, DBG, Ne, RFE y del epitelio del tabique nasal (RE) en ratas macho de 5, 15, 25 y 35 días de edad. Las VBG y JG fueron intensamente positivas a la reacción de PAS desde los 5 días de edad y débilmente positivas a la reacción de AB desde los 15 días de edad, pero no a los 5 días de la edad. Las JG y VBG fueron fuertemente positivas a la immunolocalización del AR en las edades estudiadas (15, 25 y 35 días de edad). Las DBG fueron siempre negativas a las reacciones de PAS y AB. El NE, el RFE y el RE fueron negativos. Según nuestro conocimiento, éste es el primer informe de immunolocalización del AR en el VNO y la mucosa del tabique nasal. Los actuales resultados sugieren una influencia de los andrógenos en el mecanismo por el cual entran en contacto las feromonas y el Ne, a través de la regulación por andrógenos de la secreción de las JG.

PALABRAS CLAVE: Órgano vomeronasal; Quimiorecepción; Desarrollo; Histoquímica; Inmunohistoquímica.

\section{REFERENCES}

Dominguez-Salazar, E.; Portillo, W.; Baum, M. J.; Bakker, J. \& Paredes, R. G. Effect of prenatal androgen receptor antagonist or aromatase inhibitor on sexual behavior, partner preference and neuronal Fos responses to estrous female odors in the rat accessory olfactory system. Physiol. Behav., 75(3):337-46, 2002.

Eccles, R. Autonomic innervation of the vomeronasal organ of the cat. Physiol. Behav., 28:1011-5, 1982.

Freedman, L. P. Molecular biology of steroid and nuclear hormone receptors. Birkhauser, Boston, 1998.

Gao, W.; Bohl, C. E. \& Dalton, J.T. Chemistry and Structural Biology of Androgen Receptor. Chem. Rev., 105: 335270, 2005.

Garrosa, M.; Coca, S. \& Mora, O. A. Histological development of the vomeronasal complex in the pre- and postnatal rat. Acta Otolaryngol., 102(3-4):291-301, 1986.

Katz, S. \& Merzel, J. Distribution of epithelia and glands of the nasal septum mucosa in the rat. Acta Anat (Basel), 99(1):58-66, 1977.

Keverne, E.B. Importance of olfactory and vomeronasal systems for male sexual function. Physiol. Behav., 83(2):177-87, 2004.

Mendoza, A. The mouse vomeronasal glands: a light and electron microscopical study. Chem Senses 11(4):541$55,1986$.

Merck KGaA, 64271 Darmstadt, Alemania, tel.: +49 6151 72 -0 http://www.merck-express.com/servlet/PB/show/ 1277910/109033107509es.pdf., 2004. 
Meredith, M. Sensory processing in the main and accesory olfactory systems: comparisons and contrasts. J. Steroid. Biochem. Mol. Biol., 39(4B):601-14, 1991.

Muroi, Y.; Ishii, T.; Komori, S. \& Nishimura, M. A competitive effect of androgen signaling on male mouse attraction to volatile female mouse odors. Physiol. Behav., 87(1):199-205, 2006.

Oikawa, T.; Shimamura, K.; Saito, T. R.; \& Taniguchi, K. Fine structure of the vomeronasal organ in the chinchilla (Chinchilla laniger). Jikken Dobutsu., 43(4):487-97, 1994.

Roslinski, D. L.; Bhatnagar, K. P.; Burrows, A. M. \& Smith, T. D. Comparative morphology and histochemistry of glands associated with the vomeronasal organ in humans, mouse lemurs, and voles. Anat Rec., 260(1):92-101, 2000.

Taniguchi, K.; Arai, T.; \& Ogawa. Fine estructure of septal olfatory organ of masera and its associated gland in the golden hamster. J. Vet. Med. Sci. 55(1):107-16, 1993.

Taniguchi, K.; Toshima, Y.; Saito, T. R.; \& Taniguchi, K. Development of the Bowman's and Jacobson's glands in the Japanese reddish frog, Rana japonica. J. Vet. Med. Sci., 58(1):17-22, 1996.
Vaccarezza, O. Spich, L. \& Tramezzani, J. The vomeronasal organ of the rat. J. Anat.132 (2):167-85, 1981.

Wysocki C. J. Neurobehavioral evidence for the involvement of the vomeronasal system in mammalian reproduction. Neurosci. Biobehav. Rev., 3:301-41, 1979.

Correspondence to:

Dra. María Eugenia Núñez Chichet

Area of Histology and Embryology

Dept. of Morphology and Development

Veterinary Faculty

Lasplaces 1550

Montevideo, - URUGUAY

Tel.: +598 262229 33, Fax.: +59826226413.

Email: maeugenu@gmail.com

Received: 05-05-2007

Accepted: 07-06-2007 
